\title{
Sciaphila secundiflora Thwaites ex Benth. (Triuridaceae): An unrecorded species from Korean flora
}

\author{
Eun-Young Yim, Hwa-Ja Hyun, Chang-Uk Kim¹ and Chan-Soo Kim* \\ Warm Temperate and Subtropical Forest Research Center, National Institute of Forest Science, Seogwipo 63582, Korea \\ ${ }^{1}$ Jeju Wild Flower, Private Nonprofit Organization, Seogwipo 63582, Korea \\ (Received 2 September 2017; Revised 11 September 2017; Accepted 20 September 2017)
}

\begin{abstract}
Sciaphila secundiflora occurs on Jeju Island as a second species of the genus Sciaphila in Korea. This is an important finding in relation to the flora of Korea, as species of the genus Sciaphila are concentrated mainly in Indonesia and Malaysia. Few species are found on the mainland of Asia, in Japan, Taiwan, China (Hainan), tropical Africa, Australia, and on the Pacific islands. In this paper, the species $S$. secundiflora is described and illustrated as a new record from Korea. In addition, we suggest that the species of the genus Sciaphila should be protected with regard to its habitat characteristics and for its phytogeographic and climatic significance.
\end{abstract}

Keywords: Sciaphila, first record, saprophytic herb, indicator species

The family Triuridaceae Gardner includes nine genera with approximately 55 species (Christenhusz and Byng, 2016). All species of Triuridaceae are the mycoheterotrophic plants with tiny flowers and reduced scale-like leaves. Mycoheterotrophic plants use the underground fungal network to obtain carbon. They grow in the deep shade in forests and obtain carbon from surrounding green plants through shared mycorrhizal fungi. Therefore, they are often rare and inconspicuous (Furness et al., 2002; Merckx, 2013).

The genus Sciaphila includes ca. 35 species concentrated mainly in Indonesia and Malaysia with few findings in mainland Asia, Japan, Taiwan, China (Hainan), tropical Africa, Australia and Pacific islands (van de Meerendonk, 1984; Massvan de Kamer and Weustenfeld, 1998; Ohashi, 2000). Sciaphila nana Blume, the first species in Sciaphila (Triuridaceae), was discovered from Jeju Island in 2007 (Yim et al., 2011). Recently, we found the second species, S. secundiflora on Jeju. This is also a significant finding in terms of the Korean flora.

The main objective of this study is to characterize $S$. secundiflora as a new record in Korea. In addition, we aimed at considering the potential value of Sciaphila spp. in Korea as the climate change indicator species.

Population of S. secundiflora was first found on 26 Jul 2016 at Hannam-ri, Namwon-eup, Seogwipo-si, Jeju Special SelfGoverning Province, Korea. Its presence was reconfirmed on $13 \mathrm{Jul} 2017$ at same site. Voucher specimens of S. secundiflora were deposited in the Herbarium of the Warm Temperate and Subtropical Forest Research Center, National Institute of Forest Science (Korea). We also examined the specimens of Schiaphila deposited in the Warm Temperate and Subtropical Forest Research Center, Jeju Biodiversity Research Institute (Korea), and Makino Herbarium (Japan) in order to describe this species. In addition, we investigated the habitat characteristics and distribution of the genus Sciaphila based on the collection information and relevant literatures.

\section{Taxonomic Treatment}

Sciaphila secundiflora Thwaites ex Benth., Hooker's J. Bot. Kew Gard. Misc. 7: 10, 1855.

Sciaphila tosaensis Makino, Bot. Mag. (Tokyo) 19: 140, 1905. TYPE: Japan. Shikoku. Kochi Pref. Prov. Tosa, Jul. 1906, Y. Tokihisa 24941 (neotype, MAK, designated by Ohashi et al., J. Jap. Bot. 83: 28, 2008); Seychellaria tosaensis (Makino) T. Itô, Bot. Mag. (Tokyo) 21: 85, 1907; Parexuris tosaensis (Makino) Nakai \& Maek., Iconogr. Pl. Asiae Orient. 1: 23, 1936.

\footnotetext{
*Author for correspondence: kimdaram@korea.kr
} 
Sciaphila boninensis Tuyama, Bot. Mag. (Tokyo) 50: 425, 1936. Sciaphila megastyla Fukuy. \& T. Suzuki, J. Jap. Bot. 12: 412, 1936; Sciaphila tosaensis var. megastyla (Fukuy. \& T. Suzuki) S. S. Ying., Mem. Coll. Agric. Natl. Taiwan Univ. 29: 89, 1989.

\section{Korean name: Gin-Yeong-Ju-Pul (긴영주풀) 국명신칭}

Plants saprophytic herb, white, pink or brownish to reddish purple; roots with filiform lateral branches. Stems appearing usually from July to September, simple, sometimes branched at base, erect, with a few alternate scaly leaves; $2-8(-20) \mathrm{cm}$ long, $0.2-0.7 \mathrm{~mm}$ in diameter. Leaves ovate or narrowly ovate, acuminate, 2-3.5 mm long. Inflorescences terminal racemose, erect, with 1-4(-35) flowers, male flowers towards apex, female flowers toward base; bracts narrowly ovate, scale-like, 1-4 mm long; pedicels 1-5 mm long. Male flowers 6-7 mm across; perianth $4-8$, usually 6 , connate at base, equal, narrowto linear-triangular, $2-5 \times 0.2-0.5 \mathrm{~mm}$, apex glabrous, without appendages; stamens usually 3 , subsessile. Female flowers 3-4(5) $\mathrm{mm}$ across; perianth 4-10, segments equal, apex glabrous; pistils $10-80$, free; ovary obovate, $0.5-1 \mathrm{~mm}$ long, apex rounded, densely glabrous; papillate; style clavate, inserted laterally at base, exceeding ovary; stigma with dense cylindrical papillae. Fruit achene, ca. $3.5 \mathrm{~mm}$ in diameter, obovoid, longitudinally lined, apex densely minute processes. Seed 1, ellipsoidal, 0.5$1 \mathrm{~mm}$ long, surface reticulate.

Distribution: Korea, Jeju; Japan, Honshu (Nigata, Tokyo, Shizuoka, Mie, Wakayama, Kyoto, Hyogo, and Hiroshima Prefectures), Shikoku, Kyushu and the Ryukyus (Okinawa and Iriomote-jima islands); Taiwan, Kueishan and Lanyu islands; Hong Kong; Thailand; Sri Lanka; Malaysia; New Guinea; Solomon Islands

Habitat: Evergreen broad-leaved forest dominated by Quercus acuta Thunb. and Castanopsis sieboldii (Makino) Hatus. ex T. Yamaz. \& Mashiba; co-occurred with mycoheterotrophic plants, Burmannia championii Thwaites, B. cryptopetala Makino, and Monotropa hypopithys L.; moist humus-rich soil; south-eastern face of Mt. Hallasan on Jeju Island, ca. $290 \mathrm{~m}$ above sea level; the number of individuals was very small as ca. 30. (Fig. 1)

Specimens examined: KOREA. Jeju Special Self-Governing Province: Seogwipo-si, Namwon-eup, Hannam-ri, 26 Jul 2016, Kim J. and C. U. Kim 63761 (WTFRC); Seogwipo-si, Namwon-eup, Hannam-ri, 13 Jul 2017, Yim E. Y. et al. 64478 (WTFRC).

Sciaphila secundiflora is easily distinguished from $S$. nana by the size and shape of male flower. We chose the Korean name 'Gin-Yeong-Ju-Pul' because this species has the longer

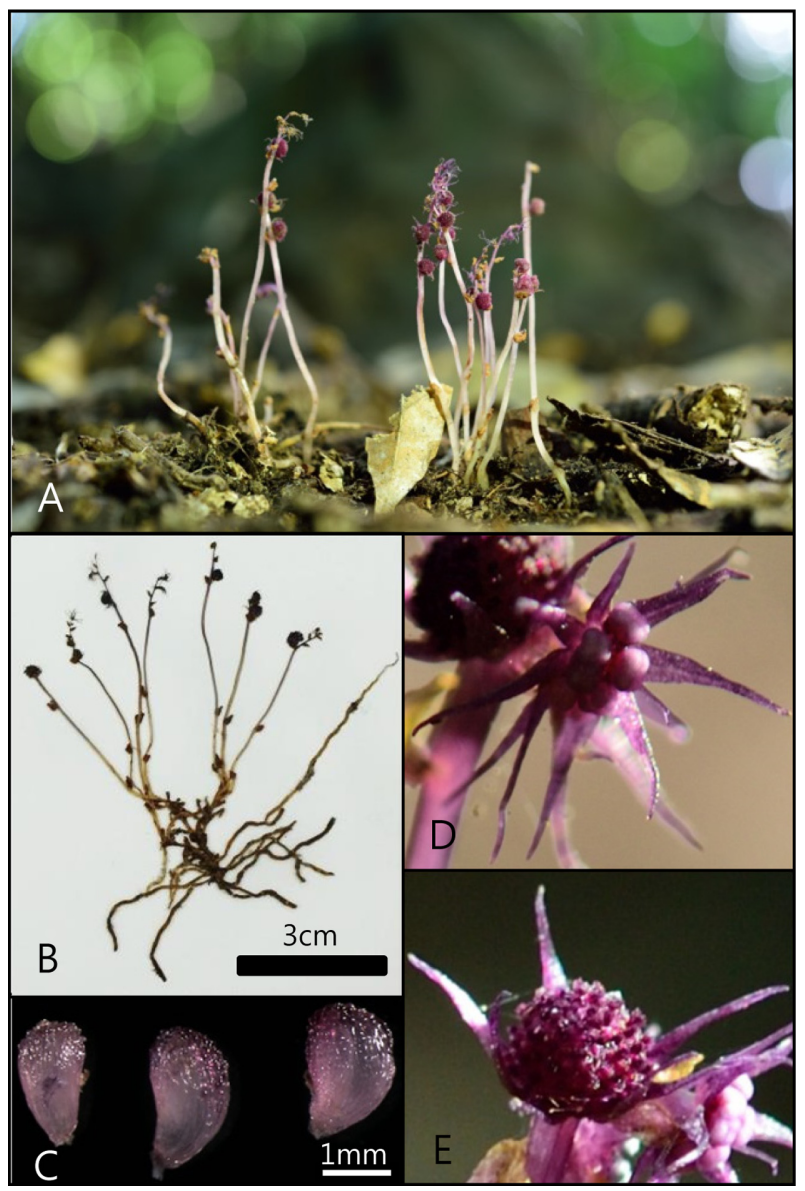

Fig. 1. Sciaphila secundiflora Thwaites ex Benth. A. Habitat. B. Specimen. C. Dissected aggregate fruit. D. Male flower. E. Female flower.

perianths than Yeong-Ju-Pul (S. nana) and 'Gin' means long in Korean.

Notes: It is known that S. secundiflora is distributed in Japan, Taiwan, Hong Kong, Thailand, Sri Lanka, Malaysia, New Guinea, and Solomon Islands. Moreover, this study presents that this species was discovered in Korea. In addition, S. nana is distributed in Korea, Japan, Thailand, Vietnam, Philippines, Malaysia, and Indonesia. The distribution of these species ranges from warm to tropical regions. The occurrence of the tropical and subtropical plants can be affected by ecosystem changes due to climate change. The world's northernmost limit of $S$. secundiflora is Nigata Prefecture, Japan, and of $S$. nana is Miyagi Prefecture, Japan (Ohashi et al., 2008). Presence of these taxa in Korea, which is located between Japan and other area, is phytogeographically and climatically significant.

Sciaphila secundiflora and S. nana occurred on the moist humus-rich soil in dense forests of Jeju and inhabit with the mycoheterotrophic plants, Burmannia championii Thwaites 
and B. cryptopetala Makino. These plants and those habitats are very rare, small, and only appear above ground when they are in flower or fruit. Therefore, the number of collections is very small, and accurate information on distribution is limited.

The plants of Sciaphila are vulnerable species to the change in environment condition (Uchida et al., 2012), and are designated as the vulnerable species or endangered species in the Red List of vascular plants in China, Japan and Taiwan. However, the criteria for conservation of these taxa and their habitats are not yet established in Korea.

We therefore suggest that further continuous monitoring on the genus Sciaphila in Korea is needed for evaluation as climate change indicator species and rare species. In addition, we think that the presence of $S$. secundiflora and $S$. nana in Korea is important for its phytogeographic and climatic significance and propose that these species should be protected at the vulnerable species level for the habitat characteristics.

\section{Key to the species of Sciaphila in Korea}

1. Male flower 6-7 $\mathrm{mm}$ in diameter; perianth without appendages at apex, equal ……........... 1. S. secundiflora

1. Male flower ca. $2 \mathrm{~mm}$ in diameter; perianth with appendages at apex, dimorphic, 3 broader ones alternating with 3 narrower ones with an elliptic knob 2. S. nana

\section{Acknowledgments}

This study was supported by the Research Fellowship Program of the National Institute of Forest Science in 2017.

\section{Literature Cited}

Christenhusz, M. J. M. and J. W. Byng. 2016. The number of known plants species in the world and its annual increase. Phytotaxa 261: 201-217.

Furness, C. A., P. J. Rudall and A. Eastman. 2002. Contribution of pollen and tapetal characters to the systematics of Triuridaceae. Plant Systematics and Evolution 235: 209-218.

Mass-van de Kamer, H. and T. Weustenfeld. 1998. Triuridaceae. In The Families and Genera of Vascular Plants. Vol. 3. Flowering Plants. Monocotyledon, Lilianae (except Orchidaceae). Kubitzki, K. (ed.), Springer, Berlin. Pp. 452-458.

Merckx, V. S. F. T. 2013. Mycoheterotrophy: an introduction. In Mycoheterotrophy. The Biology of Plants Living on Fungi. Merckx, V. S. F. T. (ed.), Springer-Verlag, New York. Pp. 117.

Ohashi, H. 2000. A new treatment in Sciaphila (Triuridaceae) in Taiwan and Japan. Taiwania 45: 351-354.

Ohashi, H., H. Kato, S. Kobayashi and J. Murata. 2008. A revision of Triuridaceae of Japan. Journal of Japanese Botany 83: $20-35$.

Uchida, S., Y. Inoue, S. Mukai and H. Tsubota. 2012. New locality of Sciaphila secundiflora Thwaites ex Benth. (Triuridaceae) on Miyajima Island, SW Japan. Hikobia 16: 193-196.

van de Meerendonk, J. P. M. 1984. Triuridaceae. In Flora Malesiana Ser. I, 10. Van Steenis, C. G. G. J. (ed.), Martinus Nijhoff, The Hague/Boston/London. Pp. 109-121.

Yim, E. Y., M. H. Kim and G. P. Song. 2011. Sciaphila nana Blume (Triuridaceae): unrecorded species from Korean flora. Korean Journal of Plant Taxonomy 41: 242-245. 